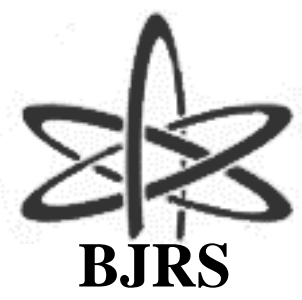

\author{
BRAZILIAN JOURNAL \\ $\mathrm{OF}$ \\ RADIATION SCIENCES \\ 08-03A (2020) 01-15
}

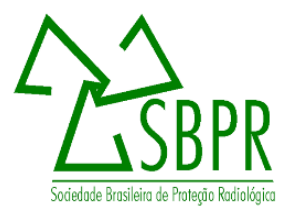

\title{
Knowledge Management in the Decommissioning of Nuclear Facilities in Brazil
}

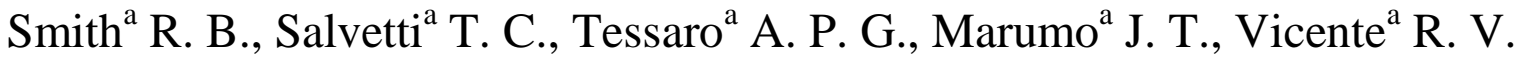 \\ ${ }^{a}$ Waste Management Department / Nuclear and Energy Research Institute (IPEN/CNEN-SP), \\ Av. Professor Lineu Prestes, 2242, 05508-000, São Paulo, SP, Brazil \\ rbsmith@ipen.br
}

\begin{abstract}
In the second half of the twentieth century in Brazil, several nuclear facilities were built for the most varied objectives. The largest number of such facilities is at the Nuclear and Energy Research Institute in São Paulo (IPEN-CNEN/SP). For different reasons, some of these facilities had their projects finalized and were deactivated. Some of the equipment was then dismantled, but the respective nuclear and radioactive material remained isolated in the original sites waiting for the proper decommissioning procedures. The Celeste Project is an example of a facility where the nuclear material has been kept, and is subject to Argentine-Brazilian Agency for Accounting and Control of Nuclear Materials (ABACC) periodic inspections. Because of a number of interests, including financial and/or budgeting situations at the institutions, decades have passed without any further action; the people who originally worked there, and possessed information and knowledge about these facilities, have already moved away from the area, or are in the process of. Therefore, because of the absence of knowledge management techniques in force at the time of establishing and operating these installations, this work proposes an analysis about the possible consequences in case of loss of perhaps the only one remaining knowledge, the one from the people who designed those departments and worked there.
\end{abstract}

Keywords: knowledge management, decommissioning, nuclear legacy, Celeste project, IPEN facilities. 


\section{INTRODUCTION}

Management with focus in knowledge is a recently new subject and consists in identifying and analyzing the existing knowledge, which help in the optimization on development of some process (such as a company). It can be said that it is an area of multidisciplinary practice, encompassing management strategy, information system and information technology; and broader areas such as economics, psychology and marketing [1].

According to Drucker [2], knowledge management is the ability to manage, identify, map, classify, capture, distribute, create, multiply and store knowledge with efficiency, efficacy and effectiveness.

Historically there has always been concern regarding retaining information and knowledge. From the stone age, cave paintings taught how to build weapons, portrayed the conviviality and pictured about the fire. In the same way, a few millenia before Christ, Mesopotamian peoples used imprinted symbols to disseminate their history, technologies and events. Another great example of knowledge management, considered as a model for centuries even after its destruction, is the Library of Alexandria, established in the third century BC, which was part of Mouseion, which means Museum, a religious and scientific institution that fostered a great number of researches. Much more than just a library, the strategy adopted by the managers of that time enabled it to become a nucleus of knowledge in various areas of culture, and as so it remained for several centuries.

Just like the Library of Alexandria, the Nuclear and Energy Research Institute (IPEN) exists with the mission of developing research and transmitting knowledge and information about the nuclear area, also exposing its multidisciplinarity. Founded in 1956 as the Institute of Atomic Energy (IEA), it opened the first research reactor in the southern hemisphere, and later sought to achieve Brazilian autonomy in the production of radioisotopes and nuclear fuel [3].

Despite the development in IPEN projects, no knowledge management plan was previously considered. Just like other major secular research institutions, a fraction of the knowledge has been lost over time, so that later decommissioned facilities would not have sufficient information records to prevent safe decommissioning from being costly and time consuming. 
The objective of this work is to evaluate how the knowledge management strategy and science can contribute in the long term for the preservation of information that guarantees the safety of nuclear installations in their decommissioning processes.

\section{A BRIEF HISTORY OF IPEN}

The Nuclear and Energy Research Institute (IPEN) was founded under Decree No. 39872 of August 31, 1956, at the time under the name of Institute of Atomic Energy (IEA), after Juscelino Kubitschek assumed the presidency of Brazil. Since the beginning, the growth of IPEN has been associated with IEA-R1, the first Brazilian research reactor, which came into operation in 1957, and had its official inauguration on January 25, 1958 (Figure 1). This reactor was provided by the United States through the "Atoms for Peace" program [4].

Figure 1: President Juscelino Kubitschek activates the lever that starts the IEA-R1 nuclear reactor, during its official inauguration.

The Governor of São Paulo at the time, Jânio Quadros, is watching.

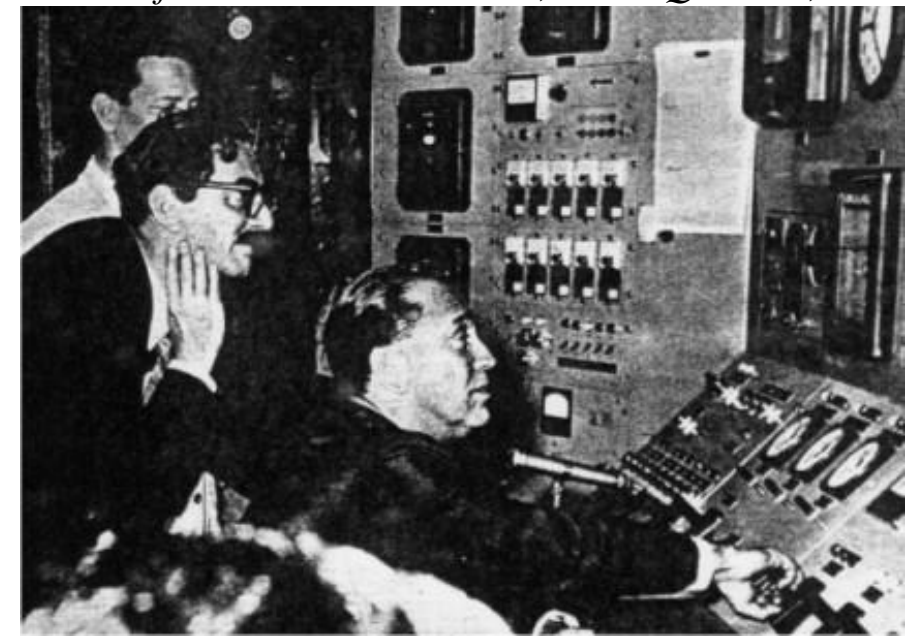

Source: [4].

Virtually since the beginning, facilities for research and development started to be built, either in pilot plant or laboratory, for the different processes in the nuclear fuel cycle of uranium and thorium. The first laboratory-scale studies date back to 1959, carried out at the time in the Division 
of Radiochemistry of the IEA. The first uranium concentrate, known as yellow-cake, was supplied by Orquima business corporation, through the National Nuclear Energy Commission (CNEN), created in October 1956.

Orquima industrialized the uranium obtained from monazite sands. Since that time, IEA has developed several activities related to the fuel cycle initiated from the yellow-cake, up to the present day at IPEN, resulting in the technology of producing silicide based dispersion fuel plates (for MTR type research reactors, such as IEA-R1), and fuel based on $\mathrm{UO}_{2}$ pellets (for PWR type power reactors).

In 1960 a pilot unit for the purification of uranium concentrates was designed and installed, for training and preparing professionals specialized in uranium chemistry. In that decade the construction of the subcritical nuclear reactor (RE-SUCO) of the Federal University of Pernambuco took place, and the IEA Nuclear Metallurgy Division manufactured the $\mathrm{UO}_{2}$-based fuel elements for the reactor [5].

From 1960 on, in the IEA Nuclear Metallurgy Division, the development of another type of dispersion-based fuel began to be studied, for application in research reactors of swimming pool type. Between 1964 and 1965 the fuel elements were manufactured for the core of the Argonauta Reactor of the Institute of Nuclear Engineering (IEN). The $\mathrm{U}_{3} \mathrm{O}_{8}$ powder used was obtained from the United States through the International Atomic Energy Agency, under the "Atoms for Peace" program. Despite the low technological requirements of the Argonauta reactor fuel, the group responsible for it planted a seed that would germinate 20 years later in the 1980s, when IPEN dominated this manufacturing technology and started producing the fuel for its research reactor IEA-R1, which required a significant technological advance in manufacturing techniques.

In 1968 the Uranium Purification Pilot Plant was completed, which went into operation in 1969. This pilot unit fulfilled the purpose of evidencing the purification process.

The Brazilian government had the ambition to develop its own nuclear technology through a gradual process of technology transfer from an international partner that already dominated the entire nuclear fuel cycle. The difficulties in the transfer of technology imposed by the United States, particularly in the area of uranium enrichment, led the government to start dealing with West Germany, with the intention of deepening the scientific cooperation between the two countries. In 1975, the Minister for Foreign Affairs of the Federal Republic of Germany and the Brazilian 
Minister Antônio Azeredo da Silveira signed in Bonn the "Agreement on Cooperation in the Field of Peaceful Use of Nuclear Energy", which covered practically the entire cycle, including:

- Prospection, extraction and processing of uranium ores;

- Conversion to $\mathrm{UF}_{6}$;

- Enrichment through the centrifugal jet;

- Reconversion of $\mathrm{UF}_{6}$ into $\mathrm{UO}_{2}$;

- Manufacture of pellets and assembly of fuel elements;

- Construction of 8 nuclear reactors of 1300 MWe over a period of 15 years;

- Reprocessing spent fuel [6].

In exchange, Brazil undertook to pay Germany the amount of 10 billion dollars, and to intensify its works on prospection, research, exploration and commercialization of natural uranium, with the objective of guaranteeing to the new partner a minimum quota of uranium ores for supplying the nuclear power plants in Germany. In fact, the nuclear agreement with Germany, besides projecting West Germany as a supplier of equipment and services in a market previously dominated by the United States, it also enabled the implementation of the first large-scale program of peaceful use of atomic energy for a developing country [7].

At the same time, the former Brazilian Company of Nuclear Technology (CBTN) was transformed into a mixed economy company - Brazilian Nuclear Companies Business Corporation (NUCLEBRÁS), which, with an even broader sphere of activity, became responsible for the integrated nuclear program. A number of other subsidiaries have been set up in the various areas of the nuclear fuel cycle, to achieve the ambitious nuclear technology transfer program from Germany.

In 1979, the Autonomous Program of Nuclear Technology (PATN) was born, directed by the armed forces: Navy, Army and Aeronautics. IPEN, which had been set aside of the official nuclear program with Germany, was included as a key component of PATN [7].

At that time an agreement was signed between the Ministry of Mines and Energy and the Secretariat of Planning, with the participation of the National Security Council and CNEN, aiming at the integration of the work carried out in the IEA in the areas of the Nuclear Fuel Cycle for the development of production technology of uranium hexafluoride $\left(\mathrm{UF}_{6}\right)$. The Conversion Area 
emerged then as a result of the scientific and technological research and development work on the Nuclear Fuel Cycle. In 1980, the Conversion Project (PROCON) was created, an agreement between the Ministry of Mines and Energy and the Government of the State of São Paulo, for the production of $\mathrm{UF}_{6}$.

In 1981, an agreement was initiated with the Ministry of the Navy, which regulates the participation of IPEN in the development program of nuclear propulsion technology, and defines an area to be assigned for the use of the Coordination of Special Projects (COPESP), currently the Technological Center of the Navy in São Paulo (CTMSP). After this agreement, the first uranium enrichment experiment is performed by ultracentrifugation, carried out in 1982 with centrifuges built entirely in Brazil. In that same year an agreement was established between the government of the State of São Paulo and CNEN, which reintegrates the activities of IPEN in the National Program of Nuclear Energy.

Continuing the development of the nuclear fuel cycle, in the 1980s the IPEN Nuclear Metallurgy Division was intensively contributing to the Navy in a joint effort to completely master the post-conversion phases of the Nuclear Fuel Cycle, increasing the efforts on the development of the reconversion, which comprises the steps of the cycle from the enriched $\mathrm{UF}_{6}$ to the nuclear fuel in its final form, ready for use in the reactors.

During this period, the CELESTE Project, a set of laboratories for the PUREX (Plutonium Uranium Recovery for Extraction) reprocessing process was in progress at IPEN, with the construction of hot cells for handling the irradiated material. The CELESTE Project (Figure 2), when in operation, would produce radioactive waste with a level of activity with a higher order of magnitude than the waste which IPEN had experience with. This led to a research and training program on waste management in overseas institutions from 1982 onwards. Researchers were sent to the KfK (Kernforschungszentrum Karlsruhe) in Germany to study the storage and immobilization of high-activity liquid waste, and the general management of radioactive waste.

The first major item of the CELESTE Project waste management program was the TERRA Project, a tank park for the storage of liquid waste from the first stage of the fission product extraction. At that time, the predictions of the CELESTE Project coordinators were very optimistic about the processing capacity of the laboratory $-1.5 \mathrm{~kg}$ of burnt fuel, with $30,000 \mathrm{MWd} / \mathrm{ton}$. This capacity would lead to the generation of a few cubic meters of waste, with sufficient activity to 
require cooling during the storage, special transfer techniques and homogenization of the waste, with technologies still absent in the country, removal of radiolysis gases and thick shielding [9].

Figure 2: CELESTE Project hot cells.

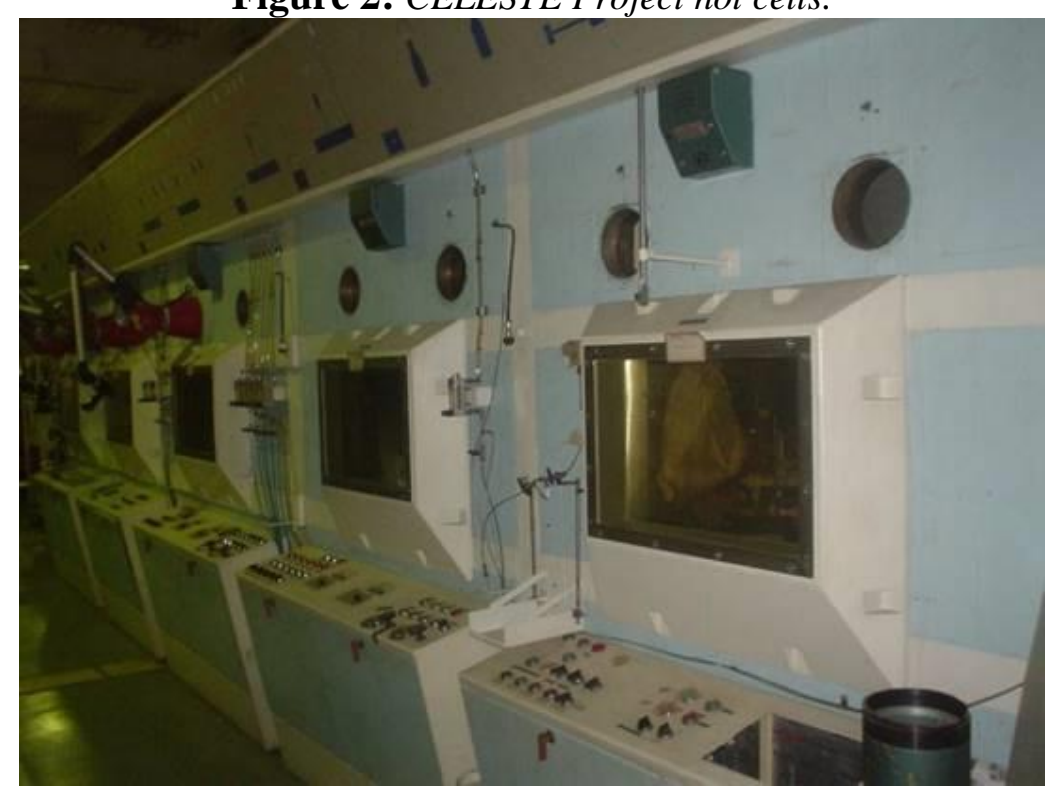

Source: [8].

The results of the research program provided significant progress in the specialization of the staff. In 1983, the first cold operation of training in irradiated material processing technology took place. The following year, the first campaign of processing irradiated materials was carried out using plutonium samples provided by the International Atomic Energy Agency (IAEA). Nevertheless, these projects were delayed for years because of lack of resources until they were shut down in the late 1980s. The CELESTE Project laboratories were allocated to other activities or closed.

The operation of the Conversion Project - PROCON plants began in 1982 and was closed in 1997, and all the conversion technology until the acquisition of $\mathrm{UF}_{6}$ was transferred to the Navy Technological Center, in Aramar. After fulfilling its historical role, the IPEN Conversion Area enabled the development of the Brazilian nuclear technology, besides developing and encouraging the human resources area, training engineers, researchers and technicians in the execution of any 
operation, whether collecting scientific and/or technological data, or collection of production data involving the most diverse chemical processes that integrate the existing processing units [5].

All of these activities of the fuel cycle, culminating in the creation of PROCON, required support in the field of analytical chemistry, bolstering the creation and strengthening of a research group of unparalleled competence in this area, of international acknowledgement. In addition, PROCON acted as a dragging project for other important projects, such as the development of thorium production technology and the production of fluoride and rare-earth elements.

In the 1990s, radical changes in the Brazilian nuclear policy resulted in the discontinuation of the fuel cycle research and, ultimately, the closure of the associated pilot plants. Unfortunately, these changes interrupted decades of autonomous research and development efforts in the nuclear fuel cycle at IPEN, with significant losses for the country. Despite the existence of a local nuclear industry currently consolidated in Brazil, the difference between autonomous development and acquisition of technology must be made clear [10].

Since then, IPEN has faced the challenge of dismantling and/or decommissioning these old pilot plants. Most facilities in the nuclear fuel cycle have been discontinued since 1993. These facilities have played an important role in the technological development and staff training, with the transfer of technology to institutions in charge of "expanding" the units [11].

Activities in most pilot plants were interrupted more than 25 years ago because of the lack of resources needed to support the research. There are a number of challenges for the decommissioning and dismantling of these facilities, such as the lack of reliable data and designs from the premises, as most of this information resided in the operators' memory and the dispersion of former operators into other activities or retirements have already occurred.

Some of these facilities at IPEN, for more than 25 years awaiting the decommissioning and dismantling procedures, receive timely visits from personnel of the Brazilian-Argentinian Agency for Accounting and Control of Nuclear Materials (ABACC) to verify and control the safeguarded materials, but so far no final decision has been made regarding the management of such materials, also because the radioactive waste storage capacity in IPEN is already depleted.

This is a brief summary of part of the story related to these facilities and that leads us to some of the reflections that originated this work. Many questions related to the data, information, technologies and knowledge generated by these activities led to the following questions: Where are 
they? Are they organized? What is the safekeeping situation? Can they be recovered? The search for answers refers to the topic of Knowledge Management, an area of science that can help us optimize such management.

\section{KNOWLEDGE MANAGEMENT}

According to Carvalho [12], information is a set of event records within a context. Knowledge is the information that, properly processed, changes the behavior of a given system.

Knowledge needs management, storage process, care to keep its information, management and channels for its proper dissemination. Knowledge encompasses intellectual human capital, the ability to research and innovate.

Briefly, it can be said that Knowledge Management is a systematic and intentional process, being supported by the generation, codification and transmission of what is known [13].

Figure 3: Organizational knowledge conversion processes.

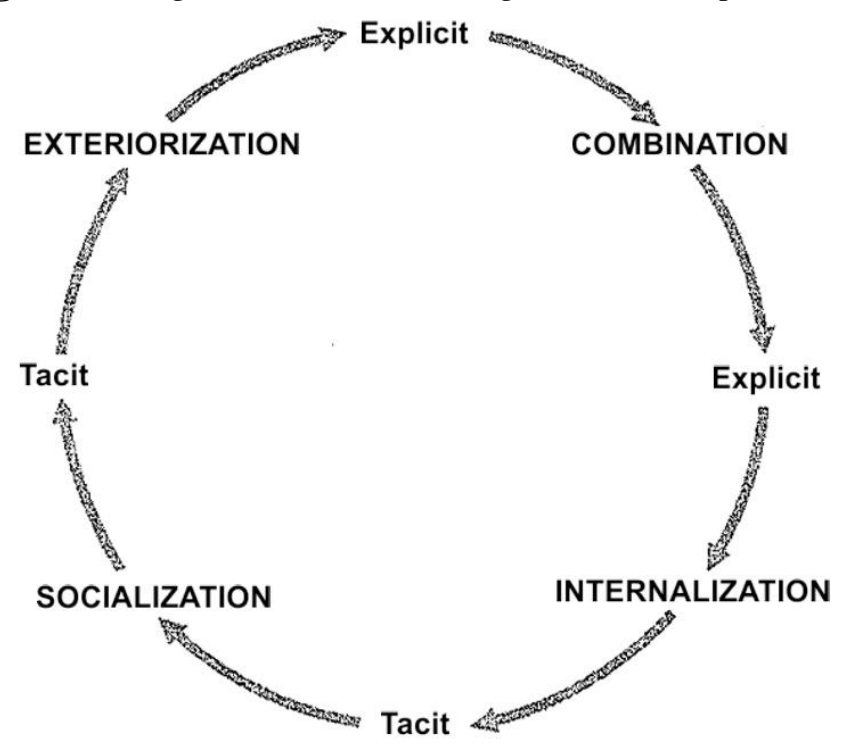

Source: adaptation of [14], p.38.

As seen in Figure 3, knowledge can be classified into two basic types: implicit (tacit) or explicit. Explicit knowledge is the easiest to be put into words, recorded and documented, acquired, for 
example, by reading manuals, books and articles. The implicit (tacit) type is the hardest to be put into words and is acquired with exercise alone. Tacit knowledge is shown only by practice, just like a leader managing his/her team, a physician making a diagnosis, or a technician opting for a more appropriate method. Very difficult to quantify and explain, one can only learn from experience, from livingness [15].

Some of the knowledge management objectives are:

- Support the generation of new knowledge;

- Identify and map knowledge and information assets linked to an organization;

- Make data accessible and useful by transforming it into information, sharing the best practices and technologies.

Some of the advantages pointed out by the adoption of a good knowledge management:

- Competitive advantage, with reduction of cost and production time;

- Greater appreciation of intellectual and human capital;

- Improvement of internal processes and greater fluidity (agility);

- More efficient decision-making processes and better results;

- Improvement of product and service quality.

The first step in management involves identifying the knowledge and defining which knowledge should be preserved. This is important for the efforts to be concentrated in the same direction, as there is knowledge that sometimes has no positive cost-benefit ratio. The next step is to transform this knowledge into processes so that, now explicit and organized, over time they are not tied to anything or anyone in particular. The third and final step is to identify which skills are important for obtaining the best results/optimization. Therefore, knowledge management corresponds to the use of a set of practices whose objective is to manage all the knowledge generated to be applied in other processes.

Some organizations face difficulties in implementing the knowledge management, such as high costs and problems in the organizational culture, as the implementation of a different culture or way of working, automating, or any kind of change, can lead to much divergence and problems. 
Therefore, looking forward to achieve greater effectiveness, the institution should plan and analyze every possible error so that the enterprise does not end up becoming a disorder, causing unnecessary expenses and losses to the organization [16].

\subsection{In the context of this work}

Essentially, "Knowledge Management (KM) is about knowledge creation, identification, apprehension and sharing. It is about getting the right knowledge in the right place at the right time, particularly if it influences an action or decision" [17].

Although information is not knowledge, it is an important aspect of knowledge, as it undergoes several transformations in which data is transformed into information, and information is transformed into knowledge, that is, the main feature of this management is based on data collection, which will later be processed to obtain a set of relevant information that will be aggregated and distributed in the form of knowledge within the organization [18].

As we have seen, knowledge is in the human and intellectual capital of the business, that is, in people. This is a key point in management, as it is necessary to identify and seek the best way to use this knowledge in the institution, focusing on better performance. Regarding the installations to be decommissioned at IPEN, most of the professionals, if not all of them, who participated in activities related to the decommissioned facilities, are in other activities or no longer at the institution. No matter the number of documents and information that still exist about the activities performed, it is necessary to recognize that part of the knowledge has been lost, as the intellectual capital is no longer available, that is, implicit knowledge. Therefore, it is understood that Information Management, combined with Knowledge Management, is a means and not an end to the success of a strategy.

In the past, the companies used to keep their knowledge well-kept and of restricted access, but with Knowledge Management the information is now transformed into knowledge and made available to any interested party. The key is to spread it throughout the organization, and not restrict it anymore [19]. At IPEN, part of the activities and practices established in these facilities are documented, however there is an inherent difficulty in finding them, as this information was 
considered to be restricted and of a confidential nature. Consequently, there is a challenge in knowing where they are.

The current moment is certainly not the most correct one, as the one mentioned by Servin [17], since the majority of the human capital involved in the activities of the facilities in question is no longer part of the group that is currently operational at IPEN.

The institution or company that intends to implement Knowledge Management needs to have clearly defined its strategic objectives and its vision for the future, as this will define the guidelines for which knowledge will be of interest to maintain or preserve. All the knowledge generated, when preserved, generates a cost inherent to the process and needs to be evaluated for its effective storage. Although it seems simple, this phase of implementation is fundamental to the success of this Management.

Therefore, this is a different situation, because in fact the proposal is to find the knowledge that was developed at that time, when there were no clear guidelines on strategic objectives or policies to do so. Once found, it is necessary to identify what is really important for the nuclear area, considering the current Brazilian nuclear policy and the interests of the institution, and to structure it in order to maintain it available for future generations or businesses. This will also allow to define profiles and competencies of potential future employees, establishing the minimum knowledge each one will need to develop for business participation. This practice is also known as Competency Management. The better this knowledge known by the employees, the greater the chances of improving business-related work processes.

One of the greatest challenges for the organizations is to apply the knowledge management in a way that is aligned to the business, directed to their strategic goals. There is no point in implementing knowledge management without thinking about which results to achieve; it is going to have little impact [20].

\section{FINAL REMARKS}

In view of the aspects presented in relation to the science of Knowledge Management, it is understood that the decommissioning and dismantling processes of the facilities that had their 
operations closed at IPEN in the 1990s would have been benefited today if the information needed to identify the premises, radioactive materials and plant operations planning had been transmitted, or even registered in accessible documents.

In light of what has been analyzed so far, it is understood that it is necessary for IPEN to define or evaluate whether its strategic objectives already incorporate the aspects related and resulting from what these facilities have aggregated of technologies and knowledge, to clearly establish the need to implement the Knowledge Management, and also elaborate the policy for such making.

Knowledge Management is already available for application in multidisciplinary fields and may well be used in the nuclear area. The institutions should just consider the future, evaluating over time which information is important, and how it should be stored in a way that could be accessible when needed.

\section{REFERENCES}

[1] FERNANDES, G. J. Gestão do Conhecimento: o que é, importância e como aplicar. FIA Business School. 2019. Available at: <https://fia.com.br/blog/gestao-do-conhecimento>. Last accessed: 20 May 2020.

[2] DRUCKER, P. F. Managing the Non-Profit Organization: Practices and Principles. Oxford, UK : Butterworth-Heinemann, 1995.

[3] LEAL, M. C. Caminhos e descaminhos do Brasil nuclear: 1945-1958. Master's degree dissertation, University Institute of Research of Rio de Janeiro. 1982. Available at:

<https://inis.iaea.org/collection/NCLCollectionStore/_Public/19/047/19047396.pdf?r=1\&r=1>. Last accessed: 20 May 2020.

[4] NUCLEAR AND ENERGY RESEARCH INSTITUTE. Marcello Damy (Série Depoimentos sobre Energia Nuclear I). São Paulo: IPEN, 1994.

[5] DURAZZO, M. História do Combustível Nuclear no IPEN. Nuclear Fuel Center, IPEN. 2015. Available at: <https://www.ipen.br/portal_por/portal/interna.php?secao_id=549>. Last accessed: 20 May 2020. 
[6] MONGELLI, S. T. Geração Núcleo-Elétrica: retrospectiva, situação atual e perspectivas futuras. Master's degree dissertation, Nuclear and Energy Research Institute. 2006. Available at: <http://www.teses.usp.br/teses/disponiveis/85/85133/tde-08062007-151208/pt-br.php>. Last accessed: 20 May 2020.

[7] BANDARRA, L. C. L. A. A luta contra o Tordesilhas Nuclear: três momentos da política nuclear brasileira (1969-1998). Master's degree dissertation, University of Brasília. 2016. Available at:

<http://repositorio.unb.br/bitstream/10482/22361/1/2016_LeonardoCarvalhoLeiteAzevedoBand arra.pdf>. Last accessed: 20 May 2020.

[8] LAINETTI, P. E. de O. Decommissioning Activities at IPEN/CNEN-SP Brazil. Chemical and Environmental Center, IPEN. 2011. Available at :

<https://www.ipen.br/biblioteca/2011/eventos/17987>. Last accessed: 20 May 2020.

[9] VICENTE, R. Alguns marcos da história da gestão dos rejeitos radioativos no IPEN. Oral communication, 2019.

[10] LAINETTI, P. E. de O. Desmantelamento e Descomissionamento de Instalações Nucleares no Brasil. Proceedings of Reunión Regional sobre Clausura de Instalaciones que Utilizan Material Radiactivo, Oct.27-31, Buenos Aires, Argentina. 2008. Available at: <https://www.ipen.br/biblioteca/2008/eventos/13601.pdf>. Last accessed: 20 May 2020.

[11] LAINETTI, P. E. de O. History of nuclear fuel cycle development, facility decommissioning and site restoration at IPEN - CNEN/SP, Brazil. Proceedings of International Symposium on Uranium Raw Material for the Nuclear Fuel Cycle: Exploration, Mining, Production, Supply and Demand, Economics and Environmental Issues (URAM-2018), Jun.25-29, Vienna, Austria. 2018. Available at: <https://conferences.iaea.org/indico/event/146/contributions/5205/contribution.pdf>. Last accessed: 20 May 2020.

[12] CARVALHO, F. C. A. Gestão do Conhecimento. São Paulo: Pearson Universities, 2012.

[13] TAKEUCHI, H.; NONAKA, I. Gestão do Conhecimento. Porto Alegre: Bookman, 2008.

[14] CHOO, C. W.; ROCHA, E. A Organização do Conhecimento: como as organizações usam a informação para criar significado, construir conhecimento e tomar decisões. São Paulo: SENAC, 2003. 
[15] CORRENTE, K. Os tipos de conhecimento: Explícito e Tácito. Administradores.com. 2016. Available at: <https://administradores.com.br/artigos/os-tipos-de-conhecimento-explicito-etacito>. Last accessed: 20 May 2020.

[16] SELDIN, R.; RAINHO, M. A. F.; CAULLIRAUX, H. M. O papel da cultura organizacional na implantação de sistemas integrados de gestão - uma abordagem sobre resistência a mudanças. Proceeding of XXIII ENEGEP, Ouro Preto, MG, Brazil, Oct.21-24, 2003.

[17] SERVIN, G. ABC of Knowledge Management. NHS National Library for Health. 2005. Available at : 〈http://www.fao.org/fileadmin/user_upload/knowledge/docs/ABC_of_KM.pdf>. Last accessed: 20 May 2020.

[18] HICKS, R. ; DATTERO, R. ; GALUP, S. The Five Tier Knowledge Management Hierarchy. Journal of Knowledge Management, v. 10, n. 1, p. 19-31, 2006.

[19] WADA, S. Os benefícios da gestão do conhecimento para as organizações. Administradores.com. 2012. Available at : <https://administradores.com.br/noticias/osbeneficios-da-gestao-do-conhecimento-para-as-organizacoes>. Last accessed: 20 May 2020.

[20] PINHEIRO, J. Modelos de Gestão do Conhecimento. Brazilian Society of Knowledge Management. 2012. Available at: <http://www.sbgc.org.br/blog/modelos-de-gestao-doconhecimento>. Last accessed: 20 May 2020. 